\title{
Tariffs and Total Factor Productivity: The Case of Ghanaian Manufacturing Firms
}

\author{
Charles Ackah $^{1 *}$, Ernest Aryeetey ${ }^{2}$, Oliver Morrissey ${ }^{3}$ \\ ${ }^{1}$ Institute of Statistical, Social and Economic Research, University of Ghana, Legon, Ghana \\ ${ }^{2}$ University of Ghana, Legon, Ghana \\ ${ }^{3}$ School of Economics, University of Nottingham, Nottingham, UK \\ Email: "akaobo@yahoo.com
}

Received February 22, 2012; revised March 19, 2012; accepted April 29, 2012

\begin{abstract}
This paper investigates the effects of trade liberalization on firm productivity in Ghana. We examine Ghanaian trade policy from 1993 to 2002, a period during which trade liberalization deepened with intermittent protection in a number of ways across industries, to investigate the effects of trade policy reforms and firm productivity. We find a strong negative impact of nominal tariffs on firm productivity, controlling for observed and unobserved firm characteristics and industry heterogeneity, a result that is robust to various alterations of the base model, including treating tariffs as endogenous and employing different estimation techniques. These results indicate that firms that are overprotected have a lower level of Total Factor Productivity than firms that are exposed to import competition. The estimated coefficients on both tariffs and its squared term confirm that higher tariffs are particularly distortionary.
\end{abstract}

Keywords: Tariffs; Trade liberalization; Productivity; Manufacturing; Ghana

\section{Introduction}

Since the 1980s, most countries in Sub-Saharan Africa (SSA), under the auspices of the Bretton Woods institutions and within the framework of the Structural Adjustment Programes (SAPs), have departed from inwardlooking protectionist development strategies, as a reaction to the disappointment of previous import substitution industrialization policies. Trade policy reforms-tariff reduction and removal of non-tariff barriers-was an important element of the reforms. There is by now a rapidly growing literature on the impact of trade liberalization on productivity levels and growth in the manufacturing sectors of developing countries. The conventional theoretical argument is that trade liberalization would lead to significant gains in productivity. However, the theoretical literature has not yielded a definite prediction on the direction of causality. Supporters of trade liberalization claim that liberalization will raise productivity through at least two pathways. First, increased foreign competitive pressure faced by domestic producers from import competetion can result in higher productivity supposing they eliminate slack, cut costs and use inputs more efficiently to remain competitive. This effect is referred to in the literature as the elimination of "X-inefficiency" among firms in import-competing industries [1]. A process of selection is expected to occur following trade liberaliza-

${ }^{*}$ Corresponding author. tion during which the most productive firms survive and thrive while the inefficient ones exit. As a result, the average productivity across firms increases [2]. Second, trade liberalization may result in productivity gains through more access to foreign technology [3]. This may occur through the importation of capital goods and intermediate inputs embodying technologies previously unavailable to the domestic firms. Also, trade liberalization may increase productivity through technology diffusion by allowing domestic producers to learn from imported finished goods as well as from exporting.

Given the apparent ambiguity in the theoretical literature summarized above, the relationship between trade liberalization and productivity appears an empirical mater. However, the available empirical evidence on the issue has been far from conclusive ${ }^{1}$. Unlike other regions, there exists a paucity of empirical research on how trade reforms have impacted firm performance in SSA. This is in part due to the non-availability of reliable firm-level panel data. In this paper, we match manufacturing firm-level panel data with commodity-level disaggregated data on import tariffs to examine the effects of trade liberalization on firm performance in one of Africa's most devout reformers: Ghana-Africa's once adjustment star pupil. We investigate the

${ }^{1}$ In recent years, in particular, considerable attempts have been made to investigate the channels through which trade liberalization affects firm productivity in developing countries. Good examples are the studies of [4-6], and [1] for Chile, India, Indonesia and Colombia, respectively. 
effects of import tariff reductions on total factor productivity (TFP) of Ghanaian manufacturing firms over the period 1993-2002.

The results from the paper contribute to the ongoing theoretical and empirical debate on trade openness, productivity and growth. We find relatively large positive effects of tariff reductions on total factor productivity, a result that is robust to various alterations of the base model, including treating tariffs as endogenous and employing different estimation techniques. We note that these effects seem consistent with the hypothesis that trade liberalization has increased productivity in the domestic market. These results indicate that firms that are overprotected as illustrated by high import tariffs pertaining to the industries in which they operate have a lower level of TFP than firms that are exposed to competition. We find also a strong effect of export intensity on productivity, both on its own and in conjunction with lower tariffs. Exporters appear to take more advantage of foreign competition than non-exporters and appear more sensitive to tariffs.

The remainder of the paper is organized as follows: Section 2 presents our empirical approach to productivity measurement and the examination of how trade policy affects measured productivity. Section 3 discusses the data used in the econometric analysis. The results are summarized in Section 4, Section 5 conclusions.

\section{Econometric Analysis}

Our baseline specification is a standard Cobb-Douglas production function which links output with inputs and the firm's productivity as follows:

$$
y_{i j t}=\beta_{m} m_{i j t}+\beta_{l} l_{i j t}+\beta_{k} k_{i j t}+w_{i j t}+\eta_{i j t}
$$

where $y_{i j t}$ denotes log real output, $m_{i j t}$ is log intermediate materials, $k_{i j t}$ is log physical capital, $l_{i j t}$ is $\log$ employment, $w_{i j t}$ is total factor productivity (TFP), $\eta_{i j t}$ is a random disturbance, $\beta_{m}, \beta_{l}$, and $\beta_{k}$ are input elasticities, and $i, j, t$ denote firm, sector and time, respectively. If we assume that the share of intermediate input in output is constant, the output production function can be re-written as a value-added specification. We report results for both specifications below.

Firm productivity is an unobservable firm characteristic, which can be recovered from estimating the production function (1) using actual input quantities. The basic problem in estimating (1) is that the input variables are in general correlated with the unobserved productivity shock, $w_{i j t}$, but might not be observed by the econometrician, leading to the well-known simultaneity problem in production function estimation ${ }^{2}$. Several solutions have

\footnotetext{
${ }^{2}$ There are problems with estimating Equation (2) with OLS; the method could be biased and would yield biased estimates of TFP if it turns out that the productivity shock in (2) is not orthogonal to the factor inputs as is implicit in OLS. See $[7,9,10]$.
}

been proposed to address this econometric problem. In the most recent best-practices, firm-level TFP is calculated following the innovations espoused by [7] that corrects the simultaneity bias arising from the fact that firms choose their levels of input once they know their levels of productivity ${ }^{3}$. The method also corrects the selection bias induced by the fact that firms choose to stay or exit the market depending on their levels of productivity, which in turn depend on the levels of their fixed factor input, namely capital stock. The authors propose to overcome the simultaneity problem by using the firm's investment as a proxy for unobserved productivity shocks.

Other best-practice methods such as the within-group and GMM-type estimators (e.g., [8]) have also been extensively employed to correct for simultaneity biases but it is believed that (if properly done) the Olley-Pakes estimator has several advantages as it does not assume that the firm-specific productivity component $w_{i j t}$ reduces to a fixed firm-effect and hence is a less costly solution to the omitted variable and/or simultaneity problem. The problem with the Olley-Pakes estimator is that the procedure requires strictly positive investment, meaning that all observations with zero investment have to be dropped from the data. This condition may imply a considerable drop in the number of observations because often firms do not have positive investment in every year ${ }^{4}$. More recently, [10] propose an estimation methodology that corrects the simultaneity bias using intermediate input expenditures, such as material inputs, as a proxy. This is especially useful as there are many firm-level datasets containing significantly less zero-observations in intermediate inputs than in firm-level investment.

For a start, we follow [11-13] and use the "direct approach" to estimating production functions to estimate (1). To account for the simultaneity of input choices and unobserved productivity, we use the System-GMM estimator of Blundell and Bond (1998). We use twice lagged inputs and output as instruments in the differenced equation and lagged first-differences of inputs are instruments in the level equation. For comparison, we also estimated (1) with OLS and Fixed-effects estimators. The results of these regressions are reported in Tables 1 and 2. To assess the robustness of the findings, we apply a methodology that is similar to the one used by $[1,4-6,13]$ to study the correlation between total factor productivity

\footnotetext{
${ }^{3}$ For example, if more productive firms are more likely to hire more workers and invest in more capital due to higher current and anticipated future profitability, estimation methods such as OLS will not be consistent and thereby result in biased coefficient estimates; the estimated input coefficients would be higher than their true values.

${ }^{4}$ For example, in the specific case of the data set under examination, about 32 percent of observations has zero investment while a further 44 percent has "missing" investment and therefore much information would be lost in dropping these observations, as required by the OlleyPakes technique.
} 
Table 1. Tariffs and firm-level productivity-output regressions.

\begin{tabular}{|c|c|c|c|c|c|}
\hline & OLS & $\mathrm{FE}$ & SYS-GMM & SYS-GMM & SYS-GMM \\
\hline VARIABLES & 1 & 2 & 3 & 4 & 5 \\
\hline \multirow{2}{*}{ Real Output $_{t-1}$} & & & $0.351^{* * *}$ & $0.349 * * *$ & $0.338 * * *$ \\
\hline & & & $(0.00234)$ & $(0.00232)$ & $(0.00157)$ \\
\hline \multirow[t]{2}{*}{ Employment } & $0.231 * * *$ & $0.177 * * *$ & $0.107 * * *$ & $0.114 * * *$ & $0.117^{* * *}$ \\
\hline & $(0.0154)$ & $(0.0246)$ & $(0.00376)$ & $(0.00312)$ & $(0.00382)$ \\
\hline \multirow[t]{2}{*}{ Capital Stock } & $0.0938 * * *$ & 0.00529 & $0.0982 * * *$ & $0.0977^{* * *}$ & $0.100 * * *$ \\
\hline & $(0.00661)$ & $(0.0222)$ & $(0.00217)$ & $(0.00272)$ & $(0.00185)$ \\
\hline \multirow[t]{2}{*}{ Raw Materials } & $0.756^{* * *}$ & $0.699 * * *$ & $0.458^{* * *}$ & $0.454 * * *$ & $0.470 * * *$ \\
\hline & $(0.00837)$ & -0.0112 & $(0.00204)$ & $(0.00131)$ & $(0.00176)$ \\
\hline \multirow[t]{2}{*}{ Tariff } & $-0.104^{* * *}$ & 0.00843 & $-0.152^{* * *}$ & & $-0.0955^{* * *}$ \\
\hline & $(0.0352)$ & $(0.0608)$ & $(0.00563)$ & & $(0.00394)$ \\
\hline \multirow[t]{2}{*}{ Tariff $_{t-1}$} & & & & $-0.162 * * *$ & \\
\hline & & & & $(0.00475)$ & \\
\hline \multirow[t]{2}{*}{ Export Share } & & & $0.00156 * * *$ & $0.00164 * * *$ & $0.00129 * * *$ \\
\hline & & & $(0.000112)$ & $(0.00012)$ & $(0.00009)$ \\
\hline \multirow[t]{2}{*}{ Firm Age } & & & $0.00445^{* * *}$ & $0.00443 * * *$ & $0.00399 * * *$ \\
\hline & & & $(0.000215)$ & $(0.00022)$ & $(0.00025)$ \\
\hline \multirow[t]{2}{*}{ Accra } & & & $0.151^{* * *}$ & $0.141^{* * *}$ & $0.151 * * *$ \\
\hline & & & $(0.00799)$ & $(0.0114)$ & $(0.0114)$ \\
\hline \multirow[t]{2}{*}{ Kumasi } & & & $0.157 * * *$ & $0.153^{* * *}$ & $0.162 * * *$ \\
\hline & & & $(0.00866)$ & $(0.00935)$ & $(0.00911)$ \\
\hline \multirow[t]{2}{*}{ Takoradi } & & & $0.0679 * * *$ & $0.0494^{* * *}$ & $0.0621 * * *$ \\
\hline & & & $(0.0105)$ & $(0.0124)$ & $(0.0113)$ \\
\hline \multirow[t]{2}{*}{ Constant } & $2.354 * * *$ & $5.138 * * *$ & $1.227 * * *$ & $1.344 * * *$ & $1.304 * * *$ \\
\hline & $(0.117)$ & $(0.399)$ & $(0.0339)$ & $(0.0309)$ & $(0.0367)$ \\
\hline Year Effects & yes & yes & yes & yes & yes \\
\hline Observations & 1539 & 1539 & 1255 & 1255 & 1255 \\
\hline R-squared & 0.97 & 0.79 & & & \\
\hline$m 2$ & & & 0.793 & 0.819 & 0.759 \\
\hline Sargan & & & 0.410 & 0.286 & 0.473 \\
\hline
\end{tabular}

Source: Authors' calculations; Notes: 1) Dependent variable is log real output. All inputs and tariff are in logs; 2) Standard errors are in parentheses. * significant at $10 \%, * *$ at $5 \%, * * *$ at $1 \%$; 3 ) The Sargan test is for the validity of the set of instruments. The test for 2 nd ( $m 2$ )-order serial correlation is asymptotically distributed as standard normal variables (see [8]). The p-values report the probability of rejecting the null hypothesis of serial correlation, where the first differencing will induce (MA1) serial correlation if the time-varying component of the error term in levels is a serially uncorrelated disturbance. 
Table 2. Tariffs and firm-level productivity—value added regressions.

\begin{tabular}{|c|c|c|c|c|c|c|c|}
\hline & OLS & FE & SYS-GMM & SYS-GMM & SYS-GMM & SYS-GMM & SYS-GMM \\
\hline VARIABLES & 1 & 2 & 3 & 4 & 5 & 6 & 7 \\
\hline \multirow[t]{2}{*}{ Value $_{\text {Added }_{t-1}}$} & & & $0.581^{* * *}$ & $0.579 * * *$ & $0.607 * * *$ & $0.609 * * *$ & $0.579 * * *$ \\
\hline & & & $(0.00919)$ & $(0.011)$ & $(0.00388)$ & $(0.00419)$ & $(0.00908)$ \\
\hline \multirow[t]{2}{*}{ Employment } & $0.887 * * *$ & $0.558^{* * *}$ & $0.329 * * *$ & $0.331^{* * *}$ & $0.426^{* * *}$ & $0.392^{* * *}$ & $0.320 * * *$ \\
\hline & $(0.0395)$ & $(0.069)$ & $(0.0234)$ & $(0.0234)$ & $(0.00663)$ & $(0.00749)$ & $(0.0246)$ \\
\hline \multirow[t]{2}{*}{ Capital Stock } & $0.238^{* * *}$ & 0.0474 & $0.135^{* * *}$ & $0.130^{* * *}$ & $0.0613^{* * *}$ & $0.0766^{* * *}$ & $0.149 * * *$ \\
\hline & $(0.0184)$ & $(0.0643)$ & $(0.0158)$ & $(0.0164)$ & $(0.00669)$ & $(0.0074)$ & $(0.0152)$ \\
\hline \multirow[t]{2}{*}{ Tariff } & $-0.763 * * *$ & -0.284 & $-0.148 * * *$ & & $-0.194 * * *$ & $-0.135^{* * *}$ & $-0.878 * * *$ \\
\hline & $(0.0992)$ & $(0.174)$ & $(0.0304)$ & & $(0.00697)$ & $(0.00838)$ & $(0.129)$ \\
\hline \multirow[t]{2}{*}{ Export Share } & & & $0.00194^{* *}$ & $0.00231 * * *$ & $0.00153 * * *$ & $0.0189 * * *$ & $0.00512^{* *}$ \\
\hline & & & (0.000798) & $(0.000777)$ & $(0.000195)$ & $(0.000841)$ & $(0.00204)$ \\
\hline \multirow[t]{2}{*}{$\operatorname{Tariff}_{t-1}$} & & & & $-0.150^{* * *}$ & & & \\
\hline & & & & $(0.0329)$ & & & \\
\hline \multirow[t]{2}{*}{ Tariff * Export Share } & & & & & & $-0.0736^{* * *}$ & $-0.0169 * *$ \\
\hline & & & & & & $(0.00261)$ & (0.00799) \\
\hline \multirow[t]{2}{*}{ Tariff Squared } & & & & & & & $-0.202^{* * *}$ \\
\hline & & & & & & & $(0.0368)$ \\
\hline \multirow[t]{2}{*}{ Firm Age } & & & $0.00327 * * *$ & $0.00357 * * *$ & $0.00291 * * *$ & $0.00316 * * *$ & $0.00306^{* * *}$ \\
\hline & & & $(0.00115)$ & $(0.00112)$ & $(0.000652)$ & $(0.000628)$ & (0.00119) \\
\hline \multirow[t]{2}{*}{ Accra } & & & $0.306^{* * *}$ & $0.306^{* * *}$ & $0.353^{* * *}$ & $0.361^{* * *}$ & $0.277^{* * *}$ \\
\hline & & & $(0.0522)$ & $(0.0526)$ & $(0.016)$ & $(0.0273)$ & $(0.0506)$ \\
\hline \multirow[t]{2}{*}{ Kumasi } & & & $0.375^{* * *}$ & $0.368 * * *$ & $0.391^{* * *}$ & $0.387 * * *$ & $0.360^{* * *}$ \\
\hline & & & $(0.0545)$ & $(0.0543)$ & $(0.0158)$ & $(0.0171)$ & $(0.0534)$ \\
\hline \multirow[t]{2}{*}{ Takoradi } & & & $0.190^{* * *}$ & $0.195^{* * *}$ & $0.220 * * *$ & $0.223^{* * *}$ & $0.133^{* *}$ \\
\hline & & & $(0.0703)$ & $(0.071)$ & $(0.0269)$ & $(0.0417)$ & $(0.0646)$ \\
\hline \multirow[t]{2}{*}{ Constant } & $8.147^{* * *}$ & $13.28 * * *$ & $2.775^{* * *}$ & $2.905^{* * *}$ & $3.165^{* * *}$ & $3.055^{* * *}$ & $2.001^{* * *}$ \\
\hline & $(0.254)$ & $(1.081)$ & $(0.263)$ & $(0.242)$ & $(0.0936)$ & $(0.0955)$ & $(0.281)$ \\
\hline Year Effects & yes & yes & yes & yes & yes & yes & yes \\
\hline Industry Effects & yes & yes & yes & yes & yes & yes & yes \\
\hline Observations & 1462 & 1462 & 1162 & 1162 & 1162 & 1162 & 1162 \\
\hline R-squared & 0.741 & 0.101 & & & & & \\
\hline$m 2$ & & & 0.862 & 0.864 & 0.847 & 0.868 & 0.862 \\
\hline Sargan & & & 0.198 & 0.177 & 0.561 & 0.628 & 0.217 \\
\hline
\end{tabular}

Source: Authors' calculations; Notes: 1) Dependent variable is log real value added. All inputs and tariff are in logs; 2) Standard errors are in parentheses. * significant at $10 \%, * *$ at $5 \%, * * *$ at $1 \%$; 3) The Sargan test is for the validity of the set of instruments. The test for 2 nd ( $m 2$ )-order serial correlation is asymptotically distributed as standard normal variables (see [8]). The p-values report the probability of rejecting the null hypothesis of serial correlation, where the first differencing will induce (MA1) serial correlation if the time-varying component of the error term in levels is a serially uncorrelated disturbance. 
and tariffs - a two-step estimation procedure as proposed by Olley and Pakes. Since the Levinsohn-Petrin technique imposes less stringent data requirements than the Olley-Pakes approach, we follow several recent studies by choosing to adopt the former for the estimations in this paper ${ }^{5}$.

In the first step, we estimate the production function (1) to obtain a measure of total factor productivity. We use the Levinsohn-Petrin method to estimate (1) to correct for the presence of selection and simultaneity biases in the input coefficients required to construct the measure of $\mathrm{TFP}^{6}$. In the second stage, we relate TFP to 3-digit industry tariffs and a set of firm characteristics believed to explain firm productivity. To explain TFP at the firm level, we use the following framework:

$$
\begin{aligned}
T F P_{i j t} & =\alpha_{0}+\alpha_{1} T_{F P} P_{i j t-1}+\beta^{\prime} X_{i j t} \\
& +\theta T_{j t}+\tau_{t}+\gamma_{j}+\delta_{i j}+\varepsilon_{i j t}
\end{aligned}
$$

where $T F P_{i j t}$ is total factor productivity at the firm level, $X_{i j t}$ is a vector of firm characteristics, $T_{j t}$ is the tariff variable, $\tau_{t}$ is a time-specific effect which takes into account macroeconomic shocks common to all firms, $\gamma_{j}$ is a sector-level fixed effect, $\delta_{i j}$ is a firm-level fixed effect, $\varepsilon_{i j t}$ is unobserved time varying productivity, and $\alpha, \quad \beta$ and $\theta$ are parameters to be estimated. We use the System-GMM method proposed by [14] to deal with the possible endogeneity of observable firm characteristics. [8] recommends using the lagged values of the explanatory variables in levels as instruments under the assumptions that there is no serial correlation in the error term $\varepsilon_{i j t}$ and the right-hand side variables. Thus, the GMM estimation procedure simultaneously addresses the problems of correlation and endogeneity. The consistency of the GMM estimator depends on the validity of the assumption that the error term does not exhibit serial correlation and on the validity of the instruments. By construction, the test for the null hypothesis of no first-order serial correlation should be rejected under the identifying assumption that the error is not serially correlated; but the test for the null hypothesis of no second-order serial correlation, should not be rejected. We use two diagnostics tests proposed by [8] and [14], the Sargan test of over-identifying restrictions, and whether the differenced residuals are second-order serially correlated. Failure to reject the null hypotheses of both tests gives support to our model. We also control for unobservable characteristics that may explain current intra-firm productivity by taking into account the lagged value of TFP. The results from this estimation procedure

\footnotetext{
${ }^{5}$ There See [10] for further details on the methodology. We implement this procedure using the "levpet" command in STATA, which was written by [15].

${ }^{6}$ The coefficients of the variable and fixed factor inputs are estimated at this stage. The dependent variable we use is value added (rather than gross revenue) and the GMM estimator is used.
}

are reported in Table 5.

\section{Data Description}

The data that is used in this paper is from the World Bank Regional Project on Enterprise Development (RPED) dataset. The data is available from the Centre for the Study of African Economies at Oxford University. It is a panel survey of Ghanaian manufacturing firms covering the period from 1991 to 2002 and includes value of gross production, wage bill, number of employees, value of total raw materials, energy expenses, 4 digit industry ids, value of fixed assets, and investment among other variables. We focus on the 1993-2002 period, since data on import tariffs are available only after 1992 for most of the firms. Table A1 in the Appendix gives the definitions of all variables used in the analyses. The firm-level data is matched with commodity-level disaggregated data on import tariffs to examine the effects of trade liberalization on firm performance during the 1993-2002 period. This period is characterized by Ghana's increasing openness to trade; the significant phase of trade liberalization in Ghana was undertaken during the 1980s, while the process to dismantle trade barriers in the framework of adhesion to the WTO and ECOWAS protocols concluded in the early 2000s.

Table 3 shows total real output, real value added and real inputs from 1993 to 2002. A large degree of firm heterogeneity is found in inputs and outputs. Both real total output and real value added increased by more than twice over the period. Real output per worker and real value added per worker also increased by 17 percent and 55 percent respectively over this period, suggesting that Ghana experienced a high productivity gain. The productivity gains seem to have reflected in firms becoming relatively more capital intensive-real mean capital stock increased by more than 150 percent while employment increased by about 45 percent over the decade. Tariffs declined from an average of 20 percent in 1993 to 17 percent in 2002 while imports increased by just 5 percent during the period. Tariffs for 1993 and 2002 by industry are displayed in Table 4. For the period under study, Ghanaian Most Favoured Nation (MFN) tariffs diminished slightly in all industries except for chemical products which remained at the same level.

\section{Empirical Results}

In this section, we present the results of the estimation procedure described in Section 3, as well as results from OLS and firm fixed-effects. Table 5 reports results obtained from estimating a direct production function with real total output as the dependent variable. The productivity of a firm is determined by a set of regressors that may explain heterogeneity of firm performance. These 
Table 3. Tariffs and total factor productivity.

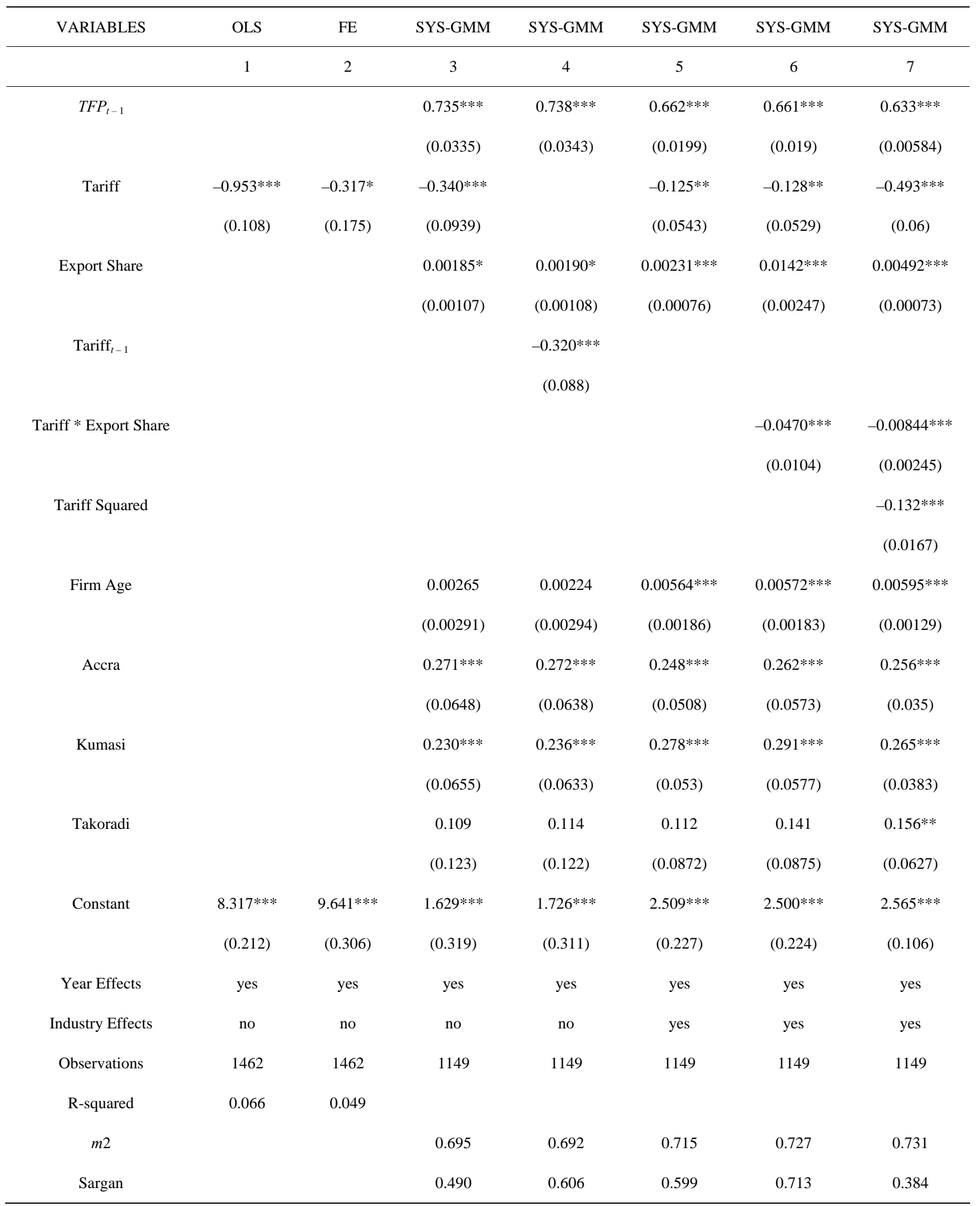

Source: Authors' calculations; Notes: 1) Dependent variable is $\ln \left(T F P_{\text {it }}\right)$ from the [10] method. All inputs and tariff are in logs; 2$)$ Standard errors are in parentheses. * significant at $10 \%, * *$ at $5 \%$, *** at $1 \% ; 3)$ The Sargan test is for the validity of the set of instruments. The test for 2 nd $(m 2)$ - order serial correlation is asymptotically distributed as standard normal variables (see [8]). The p-values report the probability of rejecting the null hypothesis of serial correlation, where the first differencing will induce (MA1) serial correlation if the time-varying component of the error term in levels is a serially uncorrelated disturbance. 
Table 4. Summary statistics.

\begin{tabular}{cccc}
\hline & 1993 & 2002 & \% Change \\
\hline Value Added & 5720 & 12,900 & 126 \\
Output/Worker & 182 & 212 & 17 \\
Value Added/Worker & 60 & 93 & 55 \\
Capital Stock & 11,600 & 29,500 & 154 \\
Employment & 46 & 67 & 45 \\
Intermediate Input & 5900 & 8690 & 47 \\
Tariff & 20 & 17 & 13 \\
Imports & 1460 & 1528 & 5 \\
\hline
\end{tabular}

Source: Authors' calculations from RPED data; Note: Output, value added, intermediate input and capital stock in real Ghana cedis.

Table 5. Nominal MFN tariffs and imports.

\begin{tabular}{ccccc}
\hline & \multicolumn{2}{c}{ Tariff (\%) } & \multicolumn{2}{c}{ Imports (1000\$) } \\
\hline Manufacture of & 1993 & 2002 & 1993 & 2002 \\
Textile \& Apparel & 22 & 19 & 998 & 619 \\
Wood \& Wood Products & 24 & 19 & 111 & 114 \\
Basic Metals & 20 & 17 & 1897 & 1433 \\
Machinery \& Equipment & 23 & 16 & 2784 & 2369 \\
Chemicals & 19 & 19 & 1697 & 1668 \\
Food \& Beverages & 13 & 12 & 2156 & 2893 \\
Average & 20 & 17 & 1460 & 1528 \\
\hline
\end{tabular}

Source: Tariff data is obtained from Ghana's Ministry of Trade; imports data is from. World Integrated Trade Solution (WITS).

include firm characteristics as well as the characteristics of the external environment in which the firm operates that can affect performance. Table 5 presents five different specifications of the determinants of firm productivity. The first and second columns present results from the estimation of the production function (1) by OLS and firm fixed effects respectively. We introduced our trade policy measure, tariff, as an additional variable to test the correlation between trade protection and firm productivity. Specification 3 expands the base model with additional covariates and estimation is done by the SYSGMM to deal with the potential endogeneity of the input variables and tariffs. If more employees are hired and more raw materials are consumed in periods of high productivity, OLS estimates of inputs' coefficients would be upwardly biased. In all specifications, we treat the input variables as endogenous using the lagged levels dated $t-2$ and before as instruments for the first-differ- enced equations and the lagged first-differences as instruments for the levels equations.

Next, we investigate if our results are robust to treating the tariff variable as endogenous. It is conceivable that the policy maker may increase trade protection in response to lobbying pressures from firms in industries with lower productivity. In such a case, tariffs become endogenous and one needs to resort to instrumental variable regressions to get consistent estimates for the tariff coefficient. In specification 4, we replace the contemporaneous tariffs with lagged tariffs as a way of partly mitigating the potential bias. Then, specification 5, we address the problem directly by estimating a specification where tariffs are instrumented by the Blundel and Bond procedure using the lagged levels dated $t-2$ and before as instruments for the first-differenced equations. For the levels equations we use the lagged first-differences as instruments. The validity of the instruments is checked by the Sargan test of over-identifying restrictions. The estimated models also satisfy the absence of second-order autocorrelation in the residuals. In all cases, the $m 2$ test does not indicate problems with the specification or validity of instruments.

The combined results from Table 3 confirm our a priori expectations. The inputs' coefficients are precisely estimated at the 1 percent confidence level. The export share and firm age variable are included in the estimations because exporters and older firms are generally expected to be relatively more productive than average. The export share has a positive and significant impact even at the 1 per cent level. This is in line with the vast literature, which has shown that exporters are typically more productive than non-exporters (see [16], for a survey). Firm age also has a positive sign, indicating that firms that have operated in Ghana for a longer time have higher productivity, compared to those that have been around for just a while. Concerning the effect of trade policy, the results provide robust evidence that indicate a large, negative and statistically significant effect of tariffs on productivity, suggesting that trade liberalization may have increased productivity in the Ghanaian manufacturing sector.

Table 2 presents results for the value added (rather than output) specification of Equation (1). The resulting tariff effects are qualitatively similar to those in Table $\mathbf{5}$. In both tables, most parameter estimates take on values within reasonable ranges, when compared to other productivity studies for African countries. In specification 6, we estimate an alternative specification allowing for a non-linear relation between productivity and export intensity. We hypothesize that the effect of trade policy on productivity may differ according the degree of export intensity of the firm. Exporting firms may benefit more from trade liberalization as they are subject more to for- 
eign competition (in foreign markets) and may be more exposed to advanced technologies. We test this hypothesis by introducing an interaction between tariffs and the export-to-output variables to allow productivity responses to vary between exporting and non-exporting firms. We are assuming that the productivity responses to trade liberalization may depend on the mode of globalization of the firm. The results of this estimation reported in column 6 confirms the previous finding of a negative and statistically significant coefficient on tariff, suggesting that, in general, a cut in tariffs increases productivity. The results further indicate a strong effect of export intensity on productivity, both on its own and in conjunction with lower tariffs. The coefficient on the interactive term is negative and statistically significant, suggesting that greater openness is likely to be associated with significantly higher productivity for exporting firms. This means that high exporters found in low tariff sectors enjoy relatively high productivity than low exporters and non-exporting firms. Hence, further trade liberalization will increase their productivity disproportionately, ceteris paribus. These findings are generally consistent with studies that have documented a positive relationship between exporting and productivity in African manufacturing industries $([17,12])$.

Finally, in column 7, we introduce squared tariff in the model in order to test for nonlinearities. The estimated coefficients on both tariffs and its squared term are negative and statistically significant, suggesting that higher tariffs are particularly adverse to productivity.

We now turn to the results from the two-step estimation procedure described in Section 3. Table 3 reports the estimation results from several specifications where we relate TFP obtained through the Levinsohn and Petrin technique to 3-digit industry tariffs and a set of firm characteristics believed to explain firm productivity. The highly significant coefficients of the import tariffs display the expected signs, confirming our previous findings. Again from the relevant specification, we find that the effects of tariffs are higher for the firms that are more globalized (export a larger share of output). In all specifications, productivity increase with the age of the firm and the share of output that is exported. The effect of tariffs on firm productivity is always negative and precisely estimated at the 1 percent confidence level or better. Tariffs are measured in fractional terms so a percentage point reduction in nominal tariffs changes productivity by $\theta$ percent. Thus, the coefficient in column 5 implies that a reduction in tariffs by say 10 percentage points would result in an increase in firm productivity of about 1.2 percent. The results in column 7 again confirm the nonlinearities in the tariff-productivity relationship. The estimated coefficients on both tariffs and its squared term confirm that higher tariffs are particularly distor- tionary. The overall results provide robust support to the hypothesis that firms operating in industries less protected from foreign competition exhibit higher productivity, ceteris paribus.

\section{Conclusions}

The role of trade policy in forging economic growth and development has been an enduring area of research for economists since the industrial revolution of the $17^{\text {th }}$ century. How does trade liberalization affect firm-level productivity? This is one of the most important questions in international economics, one that has generated a vast theoretical and empirical literature. Yet, the question continues to remain a controversial issue. This paper empirically investigates the effects of trade liberalization on firm-level productivity in Ghana. We find, in the case of Ghanaian manufacturing, that it does. We examine Ghanaian trade policy from 1993 to 2002, a period during which trade liberalization alternates with increased trade protection in varied ways across industries, to investigate the link between trade policy and firm productivity. Using a reasonably rich panel of manufacturing firms, we find a strong negative impact of nominal tariffs on firm productivity controlling for observed and unobserved firm characteristics and industry heterogeneity. The results from the paper contribute to the ongoing theoretical and empirical debate on trade openness, productivity and growth. We find relatively large positive effects of tariff reductions on total factor productivity, a result that is robust to various alterations of the base model, including treating tariffs as endogenous and employing different estimation techniques. We note that these effects seem consistent with the hypothesis that trade liberalization has increased productivity in the domestic market. These results indicate that firms that are overprotected as illustrated by high import tariffs pertaining to the industries in which they operate have a lower level of TFP than firms that are exposed to competition.

We find also a strong effect of export intensity on productivity, both on its own and in conjunction with lower tariffs. Exporters appear to take more advantage of foreign competition than non-exporters and appear more sensitive to tariffs. The negative impact of trade protection on productivity is stronger for exporting firms (or firms that export larger shares of their output) relative to non-exporting firms. The use of lagged tariffs and instrumental variable estimation techniques and the evidence on the political economy of tariff determination in Ghana allow us to argue that the negative impact of tariffs is unlikely to reflect the endogeneity of protection.

\section{Acknowledgements}

This study was made possible by financial support pro- 
vided by the International Development Research Centre (IDRC), under the "Globalization, Growth and Poverty" project. The views, interpretations, recommendations, and conclusions expressed in the paper are those of the authors and not necessarily those of IDRC.

\section{REFERENCES}

[1] A. M. Fernandes, "Trade Policy, Trade Volumes and Plant-Level Productivity in Columbian Manufacturing Industries," Journal of International Economics, Vol. 71, No. 1, 2007, pp. 52-71. doi:10.1016/j.jinteco.2006.03.003

[2] M. Melitz, "The Impact of Trade on Intra-Industry Reallocations and Aggregate Industry Productivity,” Econometrica, Vol. 71, No. 6, 2003, pp. 1695-1725. doi:10.1111/1468-0262.00467

[3] G. Grossman and E. Helpman, "Innovation and Growth in the Global Economy,” MIT Press, Cambridge, 1991.

[4] N. Pavcnik, "Trade Liberalization, Exit and Productivity Improvements: Evidence from Chilean Plants,” Review of Economic Studies, Vol. 69, No. 1, 2002, pp. 245-276. doi:10.1111/1467-937X.00205

[5] P. Topalova, "Trade Liberalization and Firm Productivity: The Case of India,” IMF Working Paper, 28 April 2004.

[6] M. Amiti and J. Konings, "Trade Liberalization, Intermediate Inputs and Productivity: Evidence from Indonesia,” American Economic Review, Vol. 97, No. 5, 2007, pp. 16111638. doi:10.1257/aer.97.5.1611

[7] G. S. Olley and A. Pakes, "The Dynamics of Productivity in the Telecommunications Equipment Industry," Econometrica, Vol. 64, No. 6, 1996, pp. 1263-1297. doi:10.2307/2171831

[8] M. Arrelano and S. Bond, "Some Tests of Specification in Panel Data: Monte Carlo Evidence and Application to Employment Equations," Review of Economic Studies, Vol. 58, No. 2, 1991, pp. 277-297. doi:10.2307/2297968
[9] J. Marschak and W. Andrews, "Random Simultaneous Equations and the Theory of Production," Econometrica, Vol. 12, No. 3-4, 1944, pp. 143-205. doi:10.2307/1905432

[10] J. Levinsohn and A. Petrin, "Estimating Production Functions Using Inputs to Control for Unobservables,” Review of Economic Studies, Vol. 70, No. 2, 2003, pp. 317-341. doi:10.1111/1467-937X.00246

[11] A. Bigsten, M. Gebreeyesus and M. Soderbom, "Gradual Trade Liberalization and Firm Response in Ethiopia," Oxford Centre for the Studies of African Economies (CSAE), Working Paper, University of Oxford, Oxford, 2009.

[12] A. Bigsten and M. Gebreeyesus, "Firm Productivity and Exports: Evidence from Ethiopian Manufacturing,” Journal of Development Studies, Vol. 45, No. 10, 2009, pp. 15941614. doi:10.1080/00220380902953058

[13] M. Dovis and Milgram-Baleix, "Trade, Tariffs and Total Factor Productivity: The Case of Spanish Firms," The World Economy, Vol. 32, No. 4, 2009, pp. 575-605. doi:10.1111/j.1467-9701.2009.01169.x

[14] R. Blundell and S. Bond, "Initial Conditions and Moments Restrictions in Dynamic Panel Data Models,” Journal of Econometrics, Vol. 87, No. 1, 1998, pp. 115-143. doi:10.1016/S0304-4076(98)00009-8

[15] A. Petrin, B. P. Poi and J. Levinsohn, "Production Function Estimation in Stata Using Inputs to Control for Unobservables,” The Stata Journal, Vol. 4, No. 2, 2004, pp. 113-123.

[16] D. Greenaway and R. Kneller, "Exporting and Productivity in the United Kingdom," Oxford Review of Economic Policy, Vol. 20, No. 3, 2004, pp. 358-371. doi:10.1093/oxrep/grh021

[17] A. Bigsten, P. Collier, S. Dercon, M. Fafchamps, B. Gauthier, J. Gunning, A. Oduro, R. Oostendorp, C. Pattillo, M. Soderbom, F. Teal and A. Zeufack, "Do African Manufacturing Firms Learn from Exporting?” Journal of Development Studies, Vol. 40, No. 3, 2004, pp. 115-141. doi:10.1080/0022038042000213229

\section{Appendix}

Table A1. List of variables and definitions-RPED panel data.

\begin{tabular}{ll}
\hline Variable Name & Variable Description \\
\hline Total Factor Productivity (TFP) & Calculated using the [10] methodology \\
Output & Real value of firm's total production during previous year \\
Physical capital stock & Real value of firm's total physical capital stock \\
Intermediate input & Real value of firm's raw material cost \\
Employment & Firm's total employment level \\
Firm age & Age of firm \\
Export share & Share of exports in firm's total output \\
Tariff & Nominal MFN tariff at the 3-digit level \\
Location & A dummy for each of the following regions: Accra, Kumasi, Takoradi. The omitted region is Cape Coast \\
\hline
\end{tabular}

